\title{
ДОСЛІДЖЕННЯ РІВНЯ БЛАГОУСТРОЮ ТЕРИТОРІЙ ЖИТЛОВИХ БУДИНКІВ \\ (НА ПРИКЛАДІ 522-ГО МІКРОРАЙОНУ м. ХАРКОВА)
}

\section{RESEARCH OF IMPROVED TERRITORY LEVEL OF RESIDENTIAL BUILDINGS}

(ON THE EXAMPLE OF THE 522nd MICRO DISTRICT OF KHARKIV)

Шишкін Е.А., к.т.н., доц., Завальний О.В., к.т.н., доц., Черноносова Т.О., ст. викл., Вяткін К.І., к.т.н., доц. (Харківський національний університет міського господарства імені О.М. Бекетова, м. Харків).

Shyshkin E.A., Ph.D. in Engineering, Associate Professor, Zavalnyi A.V., Ph.D. in Engineering, Associate Professor, Chernonosova T.O., Senior Lecturer, Viatkin K.I., Ph.D. in Engineering, Associate Professor (O.M. Beketov National University of Urban Economy in Kharkiv).

Анотація. Предметом дослідження иієї статті $\epsilon$ аналіз стану сфери благоустрою територій житлових будинків. Аналіз проведено на прикладі житлової групи будинків 522-го мікрорайону м. Харкова. За допомогою соиіологічного опитування були виявлені проблеми сфери благоустрою територій житлових будинків. На основі дослідження факторів зовнішнього та внутрішнього середовища розвитку території виконано аналіз існуючого стану об' єкта дослідження за допомогою методу SWOT-аналізу. Для вирішення основних проблем, що склалися, на об'єкті запропоновано рекомендаџї щуодо покращення стану благоустрою територї житлових будинків.

Summary. The subject of this article is an analysis of the improvement of residential areas. The analysis is carried out on the example of a residential group of houses of the 522nd microdistrict of Kharkov. Development of residential district perimeter, with the formation of residential groups with the organization of patio, protected from the harmful effects of the surrounding streets. Using a sociological survey, problems in the area of improvement of the territories of residential buildings were identified. Based on the study of factors of the external and internal environment for the development of the territory, the analysis of the existing state of the object of study using the method of SWOT analysis is performed. To solve the main problems in the territory it is proposed to: increase the level of improvement of the territory, ensuring the efficiency of its use in accordance with modern urban, sanitary and aesthetic requirements; create a public space for residents of the residential group of the 522nd residential district; increase the aesthetic attractiveness of a residential group522nd residential district; increase the number of public spaces and green spaces in the neighborhood; to create an inclusive space in a housing group; streamline transport and 
pedestrian connections, which will provide a minimum distance from house entrances to public transport stops, childcare facilities, commercial establishments, cultural and public services; to make the zoning of sites for active and passive recreation taking into account the interests of different age categories of the population and the nature of use of these sites; increase the level of use of the territory.

Further research to address these issues requires specific measures to be taken to improve this housing group, taking into account the European experience that will be outlined in subsequent publications.

Ключові слова: благоустрій територій, майданчики, прибудинкова територія, SWOT-аналіз.

Keywords: territory improvement, sites, adjoining territory, SWOT analysis.

Постановка проблеми. У містобудуванні благоустрій та озеленення $\epsilon$ складовою частиною загального комплексу заходів по плануванню, забудові та реконструкції територій населених місць.

Благоустрій міських територій - це комплекс робіт, спрямований на створення комфортних умов життєдіяльності населення. Рівень благоустрою має великий вплив на стан навколишнього середовища. Особливо цей вплив помітно проявляється у великих, крупних та найкрупніших містах. На показники стану навколишнього середовища особливо впливають щільність забудови, розвинута система транспорту, наявність та характер промисловості, наявність та санітарний стан зелених насаджень, водойм та багато іншого.

Зелені насадження $є$ важливим компонентом у ландшафті міста та мають велике рекреаційне значення. Вони найбільш ефективно підтримують природний стан біосфери, нормалізуючи температуру, вологість, загазованість та запиленість повітря, радіаційний та вітровий режими, сприяють біологічному очищенню повітря і води.

В період експлуатації будівель, споруд і комплексів спостерігаються порушення діючих нормативів i стандартів, які зачіпають питання благоустрою, що тягне за собою погіршення якості середовища проживання населення. Крім того, в даний час благоустрій прибудинкових територій $є$ морально застарілим і не відповідає сучасним соціальнопобутовим потребам населення, а також санітарно-гігієнічним та екологічним вимогам.

Житло із низьким рівнем благоустрою навколишньої території не може вважатися достатньо комфортним. Тому перед міською владою, експлуатаційними організаціями, які виконують в теперішній час не тільки функції підрядчика, але й замовника, при впорядкуванні території виникають проблеми, пов'язані із досконалістю, а частіше - зі створенням нової системи благоустрою території житлової забудови. 
Характер, склад, зміст і обсяг заходів щодо благоустрою міських територій багато в чому залежать від природно-кліматичних умов (макро- i мікроклімату); періоду будівництва існуючої забудови, стану існуючого житлового фонду; насиченості та рівня забезпеченості території установами соціально-побутового обслуговування; питомої ваги доріг 3 удосконаленими видами покриттів; наявності майданчиків різного призначення та безпечності їх обладнання; показників забезпеченості насадженнями місць загального користування тощо.

Аналіз останніх досліджень і публікацій. На сучасному етапі в нашій країні, як і в усьому світі, велике значення надається сфері благоустрою населених пунктів, що пояснюється загальним прогресом суспільства, у т.ч. підвищенням його добробуту, ускладненням структури потреб, розвитком науки, техніки, культури тощо. Заходи з благоустрою населених пунктів включають роботи щодо: відновлення, належного утримання та раціонального використання територій, охорони та організації впорядкування об'єктів благоустрою 3 урахуванням особливостей їх використання [1].

Зміст терміну «благоустрій» намагалися 3'ясувати такі вчені, як 3. Френкель, В. Зотов, Л. Веліхов, Д. Руссо, Ж. Возей, Ж. Менод, С. Пряхін та інші. Причому тривалий час термін уживався в основному щодо міських територій.

Наприклад, 3. Френкель запропонував таку дефініцію: «До загальногоміського благоустрою належать усі аспекти устрою міста, вся та частина його матеріальної культури, яка призначенням своїм має звернути місто в загальне житло - здорове, безпечне, по можливості довговічне, міцне, красиве і затишне» [2].

На думку В.Зотова, міській благоустрій $є$ насамперед загальною метою муніципальної діяльності i загальним результатом міського господарства. Немає методологічних підстав звужувати згаданий термін, віднімаючи від суми досягнень міського господарства ті чи інші галузі «благоустрою». В останньому випадку довелося б для цих галузей вибирати якийсь спеціальний термін, що 3 огляду на бідність муніципальної термінології було б утрудненим [2]. На його думку, під міським благоустроєм у вузькому розумінні слід розуміти житловий або вуличний благоустрій, як то: планування, муніципальне будівництво, житлові і земельні питання, замощення, зелені насадження, догляд за вулицями, вуличний транспорт, муніципальну зв'язок, міське освітлення та опалення. Тим часом зелені насадження $є$ не тільки зовнішнім благоустроєм, але відіграють найважливішу соціальну гігієнічну роль, а для двох останніх об'єктів, між собою мало пов'язаних, навряд чи потрібно створювати особливу категорію «зовнішнього благоустрою» [2].

Л. Веліхов під міським благоустроєм розуміє «діяльність місцевих публічних органів або організованого представництва людей, що живуть 
концентровано на обраній території і займаються переважно обробною промисловістю або торгівлею, причому ця діяльність спрямована на найвигідніше використання матеріального середовища за допомогою встановлених засобів з метою благоустрою даної територіальної одиниці і соціального добробуту». Така концепція благоустрою міста базується на більш ранній роботі 3. Френкеля «Основи загального міського благоустрою», у якій і було наведено вище представлене поняття міського благоустрою [2].

Слід відзначити діяльність французьких науковців, які продовжують робити значний внесок у розвиток проблеми благоустрою населених пунктів, зокрема щодо іiі державного регулювання та визначення соціально-економічної сутності. Так, Д. Руссо та Ж. Возей [3] пропонують розглядати термін «місцевий чи міський благоустрій» як синонім термінів: «урбанізм» та «упорядкування території», які часто важко розрізнити. Дослідники зазначають, що цю різницю неможливо виразити в кількох фразах, тому виникає потреба посилатися на більш-менш загальновідомі теорії, що поєднують ці поняття.

Серед вітчизняних науковців які займались розглядом питань стану сфери благоустрою населених пунктів, можно відмітити таких, як: О.О. Лук'янченко, Є.О. Гаркушева - щодо утримання вулично-дорожньої мережі населених пунктів [4], В.Андрійчук, С. Поталіцин - щодо зовнішнього освітлення населених пунктів [5], О.М. Бурак - щодо озеленення населених пунктів [6], В.С.Міщенко, Г.П. Виговська, Ю.М. Маковецька, Т.Л. Омельяненко - щодо поводження 3 побутовими відходами [7, 8], Т.Б. Годовська - щодо утримання місць поховань [9], Н.Олійник [10] та О. Лагоднюк [11] - щодо утримання прибудинкових територій.

Мета і завдання дослідження. Мета роботи полягала у виявленні проблеми стану прибудинкової території групи житлових будинків в 522-му мікрорайоні м. Харкова. Для досягнення цієї мети необхідно вирішити такі завдання:

1. визначити та оцінити рівень благоустрою прибудинкової території, спираючись на опитування мешканців;

2. виявити пріоритетні питання майбутнього благоустрою дворового простору, з урахуванням різних вікових груп;

3. виявити конфліктні точки експлуатації дворового простору;

4. визначити поняття «ідеальний комфортний двір» в уявленні мешканців.

Виклад основного матеріалу. Загальна характеристика об'єкта дослідження. Територія 522 мікрорайону Салтівського житлового масиву м. Харкова знаходиться на північному заході міста та обмежена: 3 північного сходу - вул. Героїв Праці, з північного заходу - вул. Академіка Барабашова, з південного сходу - вул. Академіка Павлова, $з$ південного 
заходу - вул. Валентинівською. Забудова мікрорайону - периметральна, 3 утворенням житлових груп із організацією внутрішньодворового простору, закритого від шкідливих впливів навколишніх вулиць.

Для дослідження було обрано житлову групу, що знаходиться в південно-західній частині мікрорайону (рис. 1). Ділянка по периметру обмежена: з заходу - вулицею Академіка Барабашова, з півдня - вулицею Валентинівською. Межею житлової групи, що досліджується на півночі $є$ житлові будинки іншої житлової групи мікрорайону, на сході - ліцей №107 та районний суд Шевченківського району м. Харкова, на півдні існуючий гаражний кооператив, на південному заході - ЖК «Парус».

Територія представлена багатоповерховою житловою забудовою (24 секції 12-ти поверхові та 1 секція 16-ти поверхова). Приблизна кількість мешканців в обстежених будинках становить близько 3200 осіб. На кожному поверсі розташовано по чотири квартири, тому в одній дванадцятиповерховій секції знаходиться 48 квартир, а у шістнадцятиповерховій - 64 квартири. Загальна кількість квартир складає 1280 шт. (48 квартир $\times 24$ секції +64 квартир $\times 1$ секцію). В середньому, в одній квартирі мешкають 2-3 людини, тому загальна кількість мешканців у забудові складає 3200 особи (1280 кварти $\times 2,5$ чол.).

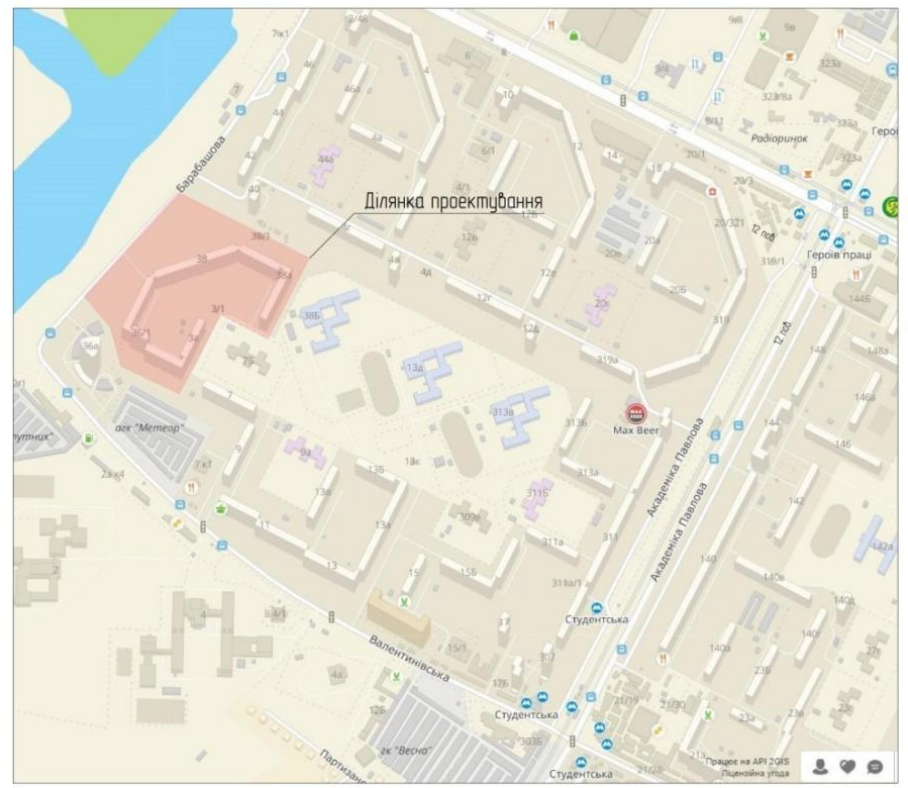

Рис. 1. Ситуаційна схема житлової забудови 522-го мікрорайону м. Харків 
Для соціологічного дослідження було обрано метод особистого інтерв'ю за сформованим інструментарієм. Знаючи соціальнодемографічну специфіку населення житлового масиву, було прийнято рішення розділити вибіркову сукупність на 5 вікових груп (табл. 1). Вибірка в даному випадку, при довірчому інтервалі 5\% і ймовірності в 90\%, буде дорівнює 245 осіб.

Таблиця 1

Вікові групи населення житлового масиву

\begin{tabular}{|c|c|}
\hline Вікова група (роки) & Кількість (у відсотках) \\
\hline Від 14 до 20 & 25,3 \\
\hline Від 21 до 30 & 18 \\
\hline Від 31 до 40 & 14,7 \\
\hline Від 41 до 50 & 15,5 \\
\hline Від 51 та старше & 26,5 \\
\hline Разом & 100 \\
\hline
\end{tabular}

Результати сочіологічного дослідження. Мешканці житлової групи, незалежно від віку, потребують покращення умов перебування на прибудинковій території. Більш за все, на дискомфортний стан дворового простору впливає:

- незадовільний стан внутрішньоквартальних проїздів (під’їзні шляхи до будинків потребують негайного ремонту) (рис. 2);

- відсутність місць для паркування автомобілів (рис. 2);

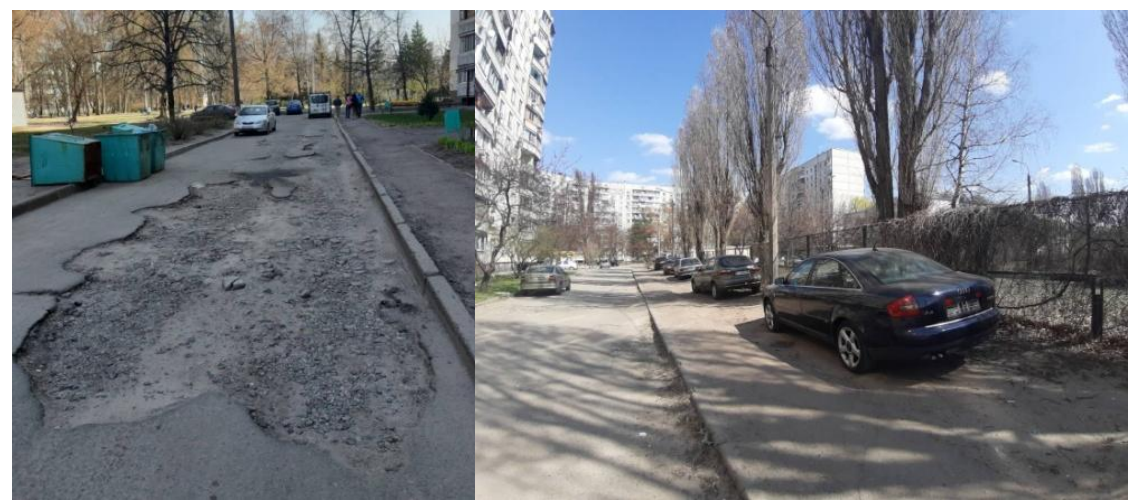

Рис. 2. Стан дорожнього покриття та місць для паркування у житловій групі

- мала кількість дитячих та спортивних майданчиків, місць для тихого відпочину та якості обладнання на цих майданчиках (кількість майданчиків недостатня або вони зовсім відсутні) (рис. 3). 


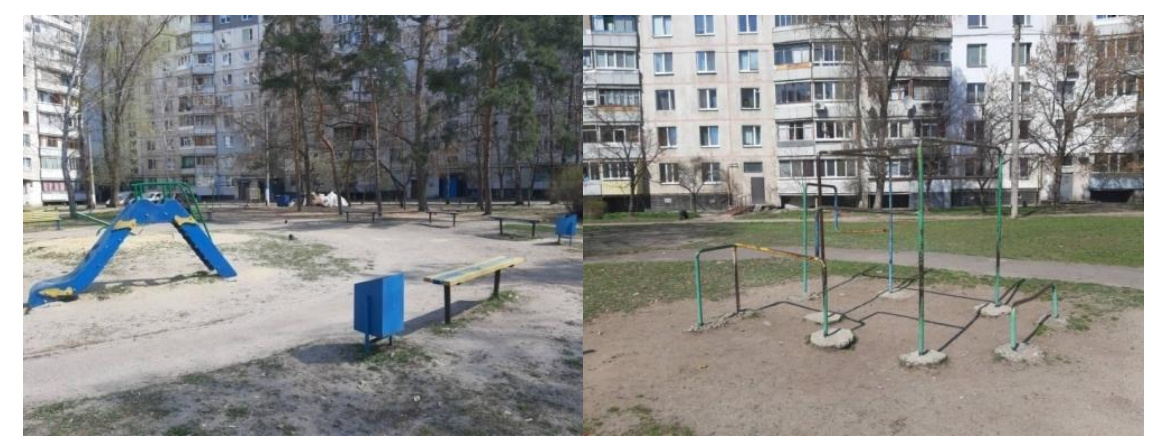

Рис. 3. Стан дитячих та спортивних майданчиків у житловій групі

Проаналізувавши відповіді мешканців будинків, можна виділити такі найболючіші проблеми:

- брак безпечних затінених місць відпочинку (дефіцит озеленення, у дворі є потенційно аварійні дерева біля входів у будинки);

- наявність наскрізного проїзду через житлову групу до будівлі районного суду;

- відсутність інфраструктури безпосередньо поблизу житлової забудови (міні-маркету, аптеки, так як всі об'єкти обслуговування розташовані біля станції метро «Студентська» на великій відстані від житлової забудови);

- недостатня кількість дитячих майданчиків на території великого двору та застаріле обладнання;

- відсутність пандусів для в 'їду в будинки та на територію двору;

- недостатня кількість на території спортивних майданчиків, тренажерів;

- відсутність столів для настільних ігор, футбольного поля;

- відсутність майданчиків для тихого відпочинку, облаштованих альтанками;

- більшість мешканців вважають, що двір великий та «незаповнений», створює відчуття пустоти.

SWOT-аналіз об'єкта дослідження. Аналіз існуючого стану територій та подальше визначення стратегічних напрямків реалізації проекту виконується на основі дослідження факторів зовнішнього та внутрішнього середовища розвитку території за допомогою методу SWOT-аналізу. Даний метод являє собою дослідження сильних і слабких сторін території, а також виявлення та оцінка зовнішніх можливостей (позитивних впливів) і загроз (небезпек), вплинути на дію яких управлінські та інші структури не можуть, але можуть їх врахувати i використовувати. Стратегічні напрямки SWOT-аналізу викладені в таблиці 2. 
Таблиця 2

SWOT-аналіз ділянки дослідження

\begin{tabular}{|c|c|c|c|}
\hline $\begin{array}{c}\text { Сильні сторони } \\
\text { внутрішні } \\
\text { (переваги) }\end{array}$ & $\begin{array}{c}\text { Слабкі сторони } \\
\text { внутрішні } \\
\text { (проблеми) }\end{array}$ & $\begin{array}{c}\text { Сильні сторони } \\
\text { зовнішні } \\
\text { (переваги) }\end{array}$ & $\begin{array}{c}\text { Слабкі сторони } \\
\text { зовнішні } \\
\text { (проблеми) }\end{array}$ \\
\hline $\begin{array}{c}\text { Вигідне } \\
\text { розташування }\end{array}$ & $\begin{array}{c}\text { Не достатньо } \\
\text { цілісна система } \\
\text { пішохідних } \\
\text { зв’язків }\end{array}$ & $\begin{array}{c}\text { Наявність у } \\
\text { пішій } \\
\text { доступності } \\
\text { дошкільного } \\
\text { закладу } \\
\text { (садка-ясел) }\end{array}$ & $\begin{array}{c}\text { Наявність у } \\
\text { пішій } \\
\text { доступність } \\
\text { ділянки } \\
\text { районного суду }\end{array}$ \\
\hline $\begin{array}{l}\text { Достатньо } \\
\text { великий } \\
\text { внутрішньо- } \\
\text { дворовий } \\
\text { простір }\end{array}$ & $\begin{array}{c}\text { Поганий стан } \\
\text { дорожнього } \\
\text { покриття } \\
\text { внутрішньо- } \\
\text { квартальних } \\
\text { проїздів та } \\
\text { тротуарів }\end{array}$ & $\begin{array}{c}\text { Наявність у } \\
\text { пішій } \\
\text { доступності } \\
\text { навчального } \\
\text { закладу (ліцею) }\end{array}$ & $\begin{array}{c}\text { Організація } \\
\text { наскрізного } \\
\text { проїзду до } \\
\text { районного суду, } \\
\text { використовуючи } \\
\text { внутрішньо- } \\
\text { квартальну } \\
\text { мережу } \\
\end{array}$ \\
\hline $\begin{array}{c}\text { Не попадає в } \\
\text { зони охорони } \\
\text { пам’яток історії } \\
\text { та культури, } \\
\text { будівництва та } \\
\text { архітектури } \\
\end{array}$ & $\begin{array}{c}\text { Недостатня } \\
\text { кількість } \\
\text { машино-місць } \\
\text { на автостоянка } \\
\text { для гостьових } \\
\text { автомобілів } \\
\end{array}$ & $\begin{array}{l}\text { Наявність у } \\
\text { пішій } \\
\text { доступність } \\
\text { гаражного } \\
\text { кооперативу }\end{array}$ & $\begin{array}{c}\text { Відсутність } \\
\text { поблизу великих } \\
\text { місць торгівлі } \\
\text { (супермаркету) }\end{array}$ \\
\hline $\begin{array}{c}\text { Розташування } \\
\text { на території } \\
\text { майданчиків } \\
\text { різного } \\
\text { призначення }\end{array}$ & $\begin{array}{c}\text { Незадовільний } \\
\text { стан обладнання } \\
\text { майданчиків } \\
\text { різного } \\
\text { призначення }\end{array}$ & $\begin{array}{c}\text { Наявність у } \\
\text { пішій } \\
\text { доступність } \\
\text { кафе, ресторану, } \\
\text { спортивного } \\
\text { залу }\end{array}$ & \\
\hline $\begin{array}{c}\text { Наявність } \\
\text { хвойних } \\
\text { насаджень }\end{array}$ & $\begin{array}{c}\text { Не відповідність } \\
\text { загальної площі } \\
\text { майданчиків } \\
\text { різного } \\
\text { призначення } \\
\text { нормованій }\end{array}$ & $\begin{array}{c}\text { Гарне } \\
\text { транспортне } \\
\text { обслуговування } \\
\text { громадського } \\
\text { транспорту }\end{array}$ & \\
\hline
\end{tabular}


Продовження таблиці 2

\begin{tabular}{|c|c|c|c|}
\hline & Дефіцит & Наявність у & \\
загальної площі & пішій & \\
і низький & доступності & \\
санітарний & зупинок & \\
станділянок & громадського & \\
& озеленення & транспорту & \\
\hline & Недостатнє & & \\
& освітлення міст & & \\
загального & & \\
& користування & & \\
\hline & Велика кількість & & \\
& необладнаних & & \\
місць торгівлі & & \\
\hline
\end{tabular}

Висновки. На основі проведеного аналізу існуючого стану прибудинкової території групи житлових будинків та соціологічного опитування мешканців житлової групи, що досліджується, були виявлені переваги та проблеми обраної ділянки дослідження. Для вирішення основних проблем, що склалися на території пропонується:

- підвищити рівень благоустрою території, забезпечивши ефективність іiі використання відповідно сучасним містобудівним, санітарним та естетичним вимогам;

- створити громадський простір для мешканців житлової групи 522го мікрорайону;

- підвищити естетичну привабливості житлової групи 522-го мікрорайону;

- збільшити кількість публічних просторів та зелених зон у мікрорайоні;

- створити інклюзивний простір у житловій групі;

- раціоналізувати транспортні та пішохідні зв'язки, які забезпечать мінімальну відстань від входів будинків до зупинок громадського транспорту, дитячих установ, підприємств торгівлі, культурно-побутового та комунального обслуговування;

- зробити зонування майданчиків для активного та пасивного відпочинку з урахуванням інтересів різних вікових категорій населення i характеру використання цих майданчиків;

- підвищити рівень використання території.

В подальших дослідженнях для вирішення викладених проблем, на нашу думку, необхідно запропонувати конкретні заходи щодо 
благоустрою даної житлової групи, враховуючи європейський досвід, котрі будуть викладені у наступних публікаціях.

\section{References}

1. On the improvement of settlements: Law of Ukraine of September 6, 2005 No. 2807-IV. Bulletin of the Verkhovna Rada of Ukraine. - 2005. - No. 49. - Art. 2580.

2. Zotov, V.B. (2005). The Municipal Management System: A Textbook for Universities. St. Petersburg. Leader, $256 \mathrm{p}$. $126 \mathrm{p}$.

3. Rousseau, D., Vauzeilles., G. (1992). L'amenagement urbain. Vendome: PUF,

4. Lukyanchenko, O.O., Harkusheva, Ye. O. (2012). Organizational and economic mechanism of development of the road sector Cities. Ekonomika budivnytstva i mis'koho hospodarstva, vol. 8, no. 1, 59-67.

5. Andriychuk, V. and Potalitsyn, S. (2012). Analysis of outdoor lighting and ways to improve their performance. Visnyk TNTU, vol. 68 , no. 4, 168-175.

6. Burak, O.M. (2009). Economic regulation of greening of cities and regions of Ukraine under Urbanization. Ph.D. Thesis, Economical science, Kharkiv National Academy of Municipal Economy, Kyiv, Ukraine, 20 p.

7. Mischenko, V.S., Makovetska, Yu.M. and Omelianenko T.L. (2012). Institutional development of the waste management in Ukraine towards European integration, Instytut ekonomiky pryrodokorystuvannia ta staloho rozvytku NAN Ukrainy, Kyiv, Ukraine.

8. Mischenko, V.S., Vyhovska, H.P., Makovetska, Yu.M. and Omelianenko, T.L. (2012). Improving waste management in Ukraine in context of European experience, Lazuryt-Polihraf, Kyiv, Ukraine. 120 p.

9. Hodovska, T. B. (2012). Features implementing environmental certification places of burial, Ekolohichna bezpeka, no. 2, 33-36.

10. Oliynyk, N.I. (2011). State regulation of the housing market in Ukraine. Ph.D. Thesis, on public administration, Kyiv, Ukraine, $391 \mathrm{p}$.

11. Lagodniuk, O.A. (2008). The concept of formation of profitable territories of settlements. Ph.D. Thesis, Kyiv, Ukraine, 16 p.

\section{Список використаної літератури}

1. Про благоустрій населених пунктів: Закон України від 06 вересня 2005 року № 2807-IV // Відом. Верхов. Ради України. - 2005. - № 49. - Ст. 2580.

2. Система муниципального управления: учебник для вузов / под ред. В. Б. Зотова. - СПб. : Лидер, 2005. - 256 с.

3. L'amenagement urbain / D. Rousseau, G. Vauzeilles. - Vendome: PUF, 1992. $-126 \mathrm{p}$.

4. Лук'янченко О. О. Організаційно економічний механізм розвитку вуличнодорожнього господарства міст / О. О. Лук'янченко, Є. О. Гаркушева // Економіка будівництва і міського господарства. - 2012. - Том 8. - № 1. - С. 59-67.

5. Аналіз систем зовнішнього освітлення та шляхів підвищення їх ефективності / В. Андрійчук, С. Поталіцин // Вісник ТНТУ. - 2012. - Том 68. - № 4. - C.168-175. 
6. Бурак О.М. Економічне регулювання розвитку системи озеленення міст та регіонів України в умовах урбанізації: автореф. дис... канд. екон. наук: 08.00 .05 / О.М. Бурак ; Харк. нац. акад. міськ. госп-ва. - Х., 2009. - 20 с.

7. Міщенко В. С. Інституціональний розвиток сфери поводження з відходами в Україні: на шляху європейської інтеграції / В.С. Міщенко, Ю.М. Маковецька, Т.Л. Омельяненко. - К: ДУ «Інститут економіки природокористування та сталого розвитку НАН України», 2013. - 192 с.

8. Міщенко В.С. Удосконалення системи управління відходами в Україні в контексті європейського досвіду / В.С. Міщенко, Г.П. Виговська, Ю.М. Маковецька, Т.Л. Омельяненко. - К. : "Лазурит-Поліграф", 2012. - 120с.

9. Годовська Т. Б. Особливості впровадження екологічної паспортизації місць поховань / Т. Б. Годовська // Екологічна безпека. - Кременчук : КрНУ, 2012. Випуск 2/2012 (14). - С. 33-36.

10. Олійник Н. І. Державне регулювання ринку житла в Україні: дис. ... д-ра наук з держ. упр. : спец. 25.00.02 / Н. І. Олійник - К., 2011. - 391 с.

11. Лагоднюк О. А. Концепція формування прибуткових територій населених пунктів : автореф. дис. канд. техн. наук : спец. 05.24.01 / Лагоднюк О. A. - K., 2008. $-16 \mathrm{c}$. 